\title{
COMMENTARY
}

\section{The host response to infection: advancing a novel diagnostic paradigm}

\author{
Geoffrey S Ginsburg*1 and Christopher W Woods ${ }^{2}$ \\ See related research by Parnell et al., http://ccforum.com/content/16/4/R157
}

\begin{abstract}
Capturing the host response by using genomic technologies such as transcriptional profiling provides a new paradigm for classifying and diagnosing infectious disease and for potentially distinguishing infection from other causes of serious respiratory illness. This strategy has been used to define a bloodbased RNA signature as a classifier for pandemic H1N1 influenza infection that is distinct from bacterial pneumonia and other inflammatory causes of respiratory disease. To realize the full potential of this approach as a diagnostic test will require additional independent validation of the results and studies to examine the specificity of this signature for viral versus bacterial infection or co-infection.
\end{abstract}

In a recent issue of Critical Care, Parnell and colleagues examined host gene expression changes in whole blood from critically ill patients infected with pandemic H1N1 influenza A infection [1]. The measurable genomic response of the host to influenza may provide important information not only on viral pathogenesis but also on the immune response, its dissemination within the infected host, and its transmission in a population. The authors evaluated transcriptional changes in blood samples obtained from 39 patients and 18 healthy controls. Of the 39 patients, eight had polymerase chain reaction (PCR)-confirmed pandemic H1N1 influenza A virus, 16 had culture-documented bacterial pneumonia, and 12 had systemic inflammatory response syndrome of undefined etiology. The investigators also enrolled three patients with apparent influenza and bacterial coinfection. A support vector machine class predictor

\footnotetext{
*Correspondence: geoffrey.ginsburg@duke.edu

IInstitute for Genome Sciences \& Policy, 101 Science Drive, Duke University, Durham, NC 27710, USA

Full list of author information is available at the end of the article
}

identified a blood-based H1N1 gene expression signature, but a separate unique bacterial signature, or secondary bacterial infection, could not be generated.

Distinguishing bacterial pneumonia from other causes of upper and lower respiratory tract infection, particularly influenza, is challenging. Improvements in the timely and accurate classification of the causative agent(s) of respiratory infection could have a profound impact on health and quality of life by improving appropriate antibiotic use and infection control interventions. The development of inexpensive and easy-to-use rapid diagnostics to accurately distinguish bacterial pneumonia from viral pneumonia in routine clinical specimens (for example, blood) would represent a major advance in health care and have a significant impact on improving the clinical management and outcome of acute pneumonias.

At present, infectious disease diagnostics focus on one or more pathogens of interest (for example, the urinary pneumococcal antigen test or multiplex PCR for respiratory viruses) or one-analyte-at-a-time biomarkers (for example, C-reactive protein or procalcitonin elevation as a marker for severe bacterial infections $[2,3]$ ). However, the sensitivity and specificity of these approaches have been limited. In other fields, high-dimensional gene expression data offer a higher level of precision in the diagnosis of acute and chronic diseases [4,5]. Infectious disease lends itself well to these analyses since the host response to pathogens entails a cascade of cellular events and expressed molecules that can be readily measured on a genome scale. The dimension and complexity of such data provide unique opportunities to uncover patterns that can distinguish subtle phenotypes in ways that traditional single-molecule techniques cannot and to use these patterns in models to predict with precision the way the genome interacts with environmental stimuli, such as infectious or other noxious agents.

Recently, strategies have been developed by several groups to use host gene expression to classify viral $[6,7]$, bacterial [8], and fungal [9] bloodstream infections - a strategy termed a 'paradigm shift' by some investigators in the field [10]. The rationale for this approach is 
clear - immune effector cells respond to pathogens with characteristic gene expression patterns reflecting the interaction of the pathogen with pattern recognition receptor signaling. These patterns, captured by microarray or alternative technologies, offer robust classification of infectious pathogens. In vitro [11-13] and ex vivo [14] data provide proof-of-concept that gene expression patterns exhibited by host immune cells have, in addition to common cellular programs, pathogenspecific components.

Parnell and colleagues should be applauded for their work in this area and extending the paradigm of hostbased classification of infectious disease. However, the study has some limitations that need to be recognized so that future investigations of this type continue to move this important area of investigation forward. The sample size is relatively small and thus the generalizability of the findings remains to be elucidated. The authors recognize that additional validations with expanded cohorts are necessary to determine whether these findings represent an H1N1-specific molecular signature or one that is more representative of influenza viruses or other respiratory pathogens [6]. In addition, the question of whether these results would be generalizable to population extremes (such as the very young or the aged and immune-compromised) and the impact of medications, particularly antiviral and other antimicrobial drugs, on the accuracy of the classifier would absolutely need to be addressed. Array-based analysis has limited utility for clinical infectious disease diagnostics, and the signatures developed here need to be migrated to a more conventional platform for diagnostics, such as reverse transcriptionPCR, and revalidated. Critical work on sample processing, turnaround time, and sensitivity, specificity, and negative and positive predictive values also would need to be assessed prior to any claims about the suitability of the signatures as a diagnostic. It is interesting that the investigators were unable to develop a signature for the bacterial pneumonia where others have had some success $[8,15]$. Perhaps this reflects the heterogeneity of the subjects, issues with accurate phenotyping, or statistical methodology limitations. Bacterial pneumonias are heterogeneous, and the details of the case definition and adjudication of the phenotypes in these types of studies are critical components of the study design. The development of a specific bacterial host response signature will be essential to the advancement of this technology to clinical application. Nonetheless, the results of this work are a significant step forward in the use of genomics to understanding the host response to an important pathogen in global health.

\section{Abbreviation}

$\mathrm{PCR}$, polymerase chain reaction.

\section{Competing interests}

Both authors are applicants for a patent to apply gene expression signatures for the diagnosis of viral infection. In addition both authors receive US government funding to study host based genomic biomarkers of infectious disease.

\section{Author details}

'Institute for Genome Sciences \& Policy, 101 Science Drive, Duke University, Durham, NC 27710, USA. IInfectious Diseases Section, Service 113, Durham VA Medical Center, Durham, NC 27705, USA.

\section{Published: 6 November 2012}

\section{References}

1. Parnell GP, McLean AS, Booth DR, Armstrong NJ, Nalos M, Huang SJ, Manak J, Tang W, Tam OY, Chan S, Tang BM: A distinct influenza infection signature in the blood transcriptome of patients who presented with severe community acquired pneumonia. Crit Care 2012, 16:R157.

2. Simon L, Gauvin F, Amre DK, Saint-Louis P, Lacroix J: Serum procalcitonin and C-reactive protein levels as markers of bacterial infection: a systematic review and meta-analysis. Clin Infect Dis 2004, 39:206-217.

3. Tsalik EL, Jaggers LB, Glickman SW, Langley RJ, van Velkinburgh JC, Park LP, Fowler VG, Cairns CB, Kingsmore SF, Woods CW: Discriminative value of inflammatory biomarkers for suspected sepsis. J Emerg Med 2012, 43:97-106.

4. Horwitz PA, Tsai EJ, Putt ME, Gilmore JM, Lepore JJ, Parmacek MS, Kao AC, Desai SS, Goldberg LR, Brozena SC, Jessup ML, Epstein JA, Cappola TP: Detection of cardiac allograft rejection and response to immunosuppressive therapy with peripheral blood gene expression. Circulation 2004, 110:3815-3821.

5. Wingrove JA, Daniels SE, Sehnert AJ, Tingley W, Elashoff MR, Rosenberg S, Buellesfeld L, Grube E, Newby LK, Ginsburg GS, Kraus WE: Correlation of peripheral-blood gene expression with the extent of coronary artery stenosis. Circ Cardiovasc Genet 2008, 1:31-38.

6. Zaas AK, Chen M, Varkey J, Veldman T, Hero AO 3rd, Lucas J, Huang Y, Turner R, Gilbert A, Lambkin-Williams R, Øien NC, Nicholson B, Kingsmore S, Carin L, Woods CW, Ginsburg GS: Gene expression signatures diagnose influenza and other symptomatic respiratory viral infections in humans. Cell Host Microbe 2009, 6:207-217.

7. Ramilo O, Allman W, Chung W, Mejias A, Ardura M, Glaser C, Wittkowski KM, Piqueras B, Banchereau J, Palucka AK, Chaussabel D: Gene expression patterns in blood leukocytes discriminate patients with acute infections. Blood 2007, 109:2066-2077.

8. Banchereau R, Jordan-Villegas A, Ardura M, Mejias A, Baldwin N, Xu H, Saye E, Rossello-Urgell J, Nguyen P, Blankenship D, Creech CB, Pascual V, Banchereau J, Chaussabel D, Ramilo O: Host immune transcriptional profiles reflect the variability in clinical disease manifestations in patients with Staphylococcus aureus infections. PLOS ONE 2012, 7:4.

9. Zaas AK, Aziz H, Lucas J, Perfect JR, Ginsburg GS: Blood gene expression signatures predict invasive candidiasis. Sci Transl Med 2010, 2:21 ra17.

10. Ramilo O, Mejias A: Shifting the paradigm: host gene signatures for diagnosis of infectious diseases. Cell Host Microbe 2009, 6:199-200.

11. Huang Q, Liu D, Majewski P, Schulte LC, Korn JM, Young RA, Lander ES, Hacohen N: The plasticity of dendritic cell responses to pathogens and their components. Science 2001, 294:870-875.

12. Jenner RG, Young RA: Insights into host responses against pathogens from transcriptional profiling. Nat Rev Microbiol 2005, 3:281-294.

13. Feezor RJ, Oberholzer C, Baker HV, Novick D, Rubinstein M, Moldawer LL, Pribble J, Souza S, Dinarello CA, Ertel W, Oberholzer A: Molecular characterization of the acute inflammatory response to infections with Gram-negative versus gram-positive bacteria. Infect Immun 2003, 71:5803-5813.

14. Cortez KJ, Lyman CA, Kottilil S, Kim HS, Roilides E, Yang J, Fullmer B, Lempicki $R$, Walsh TJ: Functional genomics of innate host defense molecules in normal human monocytes in response to Aspergillus fumigatus. Infect Immun 2006, 74:2353-2365.

15. Ardura MI, Banchereau R, Mejias A, Di Pucchio T, Glaser C, Allantaz F, Pascual V, Banchereau J, Chaussabel D, Ramilo O: Enhanced monocyte response and decreased central memory T cells in children with invasive Staphylococcus aureus infections. PLOS ONE 2009, 4:8.

doi:10.1186/cc11685

Cite this article as: Ginsburg GS, Woods CW: The host response to infection: advancing a novel diagnostic paradigm. Critical Care 2012, 16:168. 